\title{
力学的根拠に基づいた心機能の画像診断
}

\section{Diagnostic Imaging for Estimation of Cardiac Function Based on Mechanical Evidence}

○正 稲葉忠司 (三重大工)
正 小畑秀明 (岡山理大)
川崎信吾（松下記念病院）

紀ノ定保臣（岐阜大医）

松島 秀（愛知県がんセンター）

Tadashi INABA*, Shingo KAWASAKI, Shigeru MATSUSHIMA, Hideaki OBATA and Yasutomi KINOSADA *Department of Mechanical Engineering, Mie University, Kurimamachiya 1577, Tsu 514-8507, Japan

Key Words: Magnetic Resonance Tagging Technique, Myocardial Wall Motion, Circumferential Strain, Cardiac Contractility

\section{1. 粕 带}

心臟は血液循環器系における主要ポンプの役割を果 たしており，その生理的役割と運動機能とが密接に結 び付いた臟器である．それゆえ，心䇗壁の収縮運動を 力学的観点から評価することは, 心機能を解明する上 での重要な課題の一つであるとともに，心筋壁運動を 記述する力学量は, 心疾患の重症度あるいはその治療 効果を定量的に把握するための診断指標になり得ると 考えられる。このような背景から本研究では, 非侵襲 な心筋壁運動計測手法である MRI（磁気共鳴映像装 置）の tagging 法を用いて, ヒ上心臓左心室の収縮運動 を力学的に評価することを試みてきた ${ }^{[1][2] . そ の 中 か ら ~}$ 本報では，この手法を肥大型心管症，高血圧性心肥大 および払張型心筋症の心疾患患者に適用することによ り, 各種疾患心における心収縮性を力学的観点から解 明することを試みる。

\section{2. 方 法}

\section{1 撮像対象および撮像方法 本研究では, 健} 常者 10 人（年齢 $21 \sim 56$ 歳）, 肥大型心筋症 8 人（年 齢 $21 \sim 62$ 歳), 高血圧性心肥大 7 人（年齢 39 69 歳） および拡張型心筋症 2 人 (年齢 57,78 歳) を対象に撮 像を行った。撮像装置には米国 GE 社製 MRI 装置 SIGNA advantage（静磁場強度 $=1.5 \mathrm{~T}$ ) を使用し, tagging 法を用いて左心室赤道面での短軸 断面像を心電図同期下で多時相連 続撮像した. 多時相の tag 付加画像 は, 心電図ゲートの R 波の検出から $20 \mathrm{~ms}$ 後の画像を 1 枚めとして, そ の後 $25 \mathrm{~ms}$ 間隔で連続的に撮像され る. そのため, 1 枚めの画像の心時 相はほぼ拡張末期に対応する。

\section{2 解析方法 本研究では,} 心筋壁内に付加された tag の交点を 心時相を通じて連続的に追跡する ことにより，心収縮期における心䇗 壁のひずみを算出した，具体的には， 隣接する 3 つの tag 交点により構成 される三角形領域を一つの解析領 域とし, 左心室内腔中心を原点とす る極座標系における半径方向ひず み成分 $E_{r r}$, せん断ひずみ成分 $E_{r \theta}$ および円周方向ひずみ成分 $E_{\theta \theta}$ を 算出した ${ }^{[1]}$.

\section{3. 結果および考察}

既報 ${ }^{[1]}$ で示したように，健常者では，短軸断面内に おいて心筋は半径方向に伸張し, 円周方向に支配的に 収縮する。したがって, 心筋の収縮特性を評価する上 で，円周方向ひずみは極めて重要な力学量であると考 えられる. Fig. 1 に, 健常者 (normal) , 肥大型心筋症

(HCM)，高血圧性心肥大（HHD）および拡張型心䇗 症（DCM）の収縮末期における円周方向ひずみの分布 を示す，同図から，円周方向ひずみの大きさは，高血 圧性心肥大では健常者と同程度であるのに対し, 肥大 型心筋症では局所的（本症例では前壁部）に減少して いることがわかった．このことから，同じ心筋壁肥大 を伴う疾患でも，心筋症による肥大心と高血圧による 肥大心とでは心収縮性がまったく異なり，肥大型心算 症は心収縮性の低下を伴う疾患であると考えられる。 また, 拡張型心筋症では, 円周方向ひずみ值が局所的

（本症例では中隔部）に正值を示すこと，すなわち， 本来この時相において収縮すべき心筋が伸張している ことがわかった。このことから, 拡張型心䈘症は, 重 度の心収縮性低下を伴う疾患であると考えられる。

\section{文献}

[1] 稲葉・ほか, 生体医工学, 40-1 (2002), 20-27.

[2] 稲葉・ほか, 機論, 71-711, A (2005), 1595-1601.

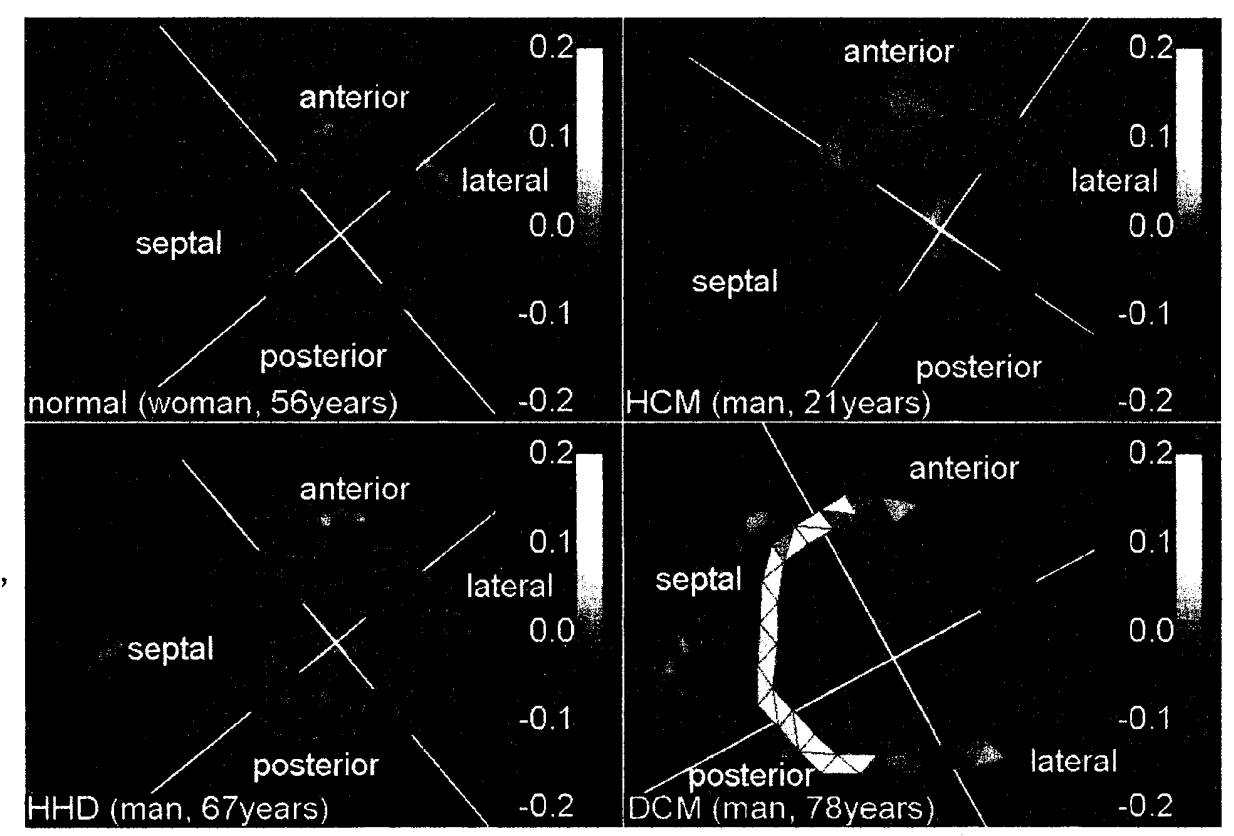

Fig. 1 Typical examples of distribution of circumferential strain at end systole 